\title{
FINANCIAL PERFORMANCE ANALYSIS WITH RADAR METHODS ON CIGARETTE COMPANIES LISTED ON IDX.
}

\author{
Ali Sadikin \\ E-mail: alisadikin@gmail.com
}

Faculty of Economics and Business, Lambung Mangkurat University, Banjarmasin

\begin{abstract}
This research was conducted on tobacco companies listed in Indonesia Stock Exchange period 2006-2008, with the intent to analyze the performance of financial statements by using radar method so it can know where the company position according to radar radar method that is profitability, productivity, asset utilization, stability and potency growth. in order to be a reference and an assessment for investors deciding to invest their funds in the company, also analyzing the industry average and the standard deviation used to determine the company's position.

The position of the company is considered good if it is in the normal range, good and very good. The results of the analysis show that PT HM Sampoerna's corporate position is better when compared with the other three companies.
\end{abstract}

Keywords: Radar Method, Industrial Average, and Deviation Standard.

\section{PENDAHULUAN}

Industri hasil tembakau (IHT) merupakan salah satu sektor strategis domestik yang memiliki daya saing tinggi dan terus memberikan kontribusi signifikan terhadap perekonomian nasional. Sumbangan sektor yang dikategorikan sebagai kearifan lokal ini meliputi penyerapan tenaga kerja, pendapatan negara melalui cukaiserta menjadi komoditas penting bagi petani dari hasil perkebunan berupa tembakau dan cengkeh.

Salah satu industri yang mempunyai persaingan sangat ketat adalah industri rokok. Selama kurun waktu 2004-2008 pertumbuhan industri rokok $(18,6 \%)$ jauh melampaui pertumbuhan penduduk (6,0\%). Lebih dari 225 miliar batang rokok diproduksi tiap tahun.

Tabel 1. Pertumbuhan Produksi Rokok Nasional Periode 2000-2008

\begin{tabular}{|l|c|c|}
\hline Tahun & Total Produksi & $\%$ Tumbuh \\
\hline 2000 & 213 miliar batang & - \\
\hline 2001 & 198 miliar batang & $(7.6 \%)$ \\
\hline 2002 & 186 miliar batang & $(6.5 \%)$ \\
\hline 2003 & 173 miliar batang & $(7.5 \%)$ \\
\hline
\end{tabular}




\begin{tabular}{|l|c|c|}
\hline 2004 & 194 miliar batang & $10.8 \%$ \\
\hline 2005 & 202 miliar batang & $(0.5 \%)$ \\
\hline 2006 & 220 miliar batang & $8.2 \%$ \\
\hline 2007 & 226 miliar batang & $2.7 \%$ naik \\
\hline 2008 & 230 miliar batang & $1.7 \%$ naik \\
\hline
\end{tabular}

Sumber: data diolah.

Dari tabel di atas, dapat disimpulkan bahwa pertumbuhan rokok di Indonesia negatif yakni dari 213 miliar batang pada tahun 2000 menjadi 194 miliar batang pada tahun 2004 atau turun sebesar 8,9 \%. Tetapi dari tahun 20042008, industri rokok malah tumbuh subur. Produksi rokok naik hingga $18,6 \%$ selama 4 tahun atau rata-rata tumbuh 4,6\% tiap tahunnya.

Berbagai inovasi yang dilakukan perusahaan untuk mencapai tujuannya dapat dilihat ketika perusahaan melakukan evaluasi. Salah satu alat keuangan yang dapat membantu perusahaan untuk melakukan evaluasi kinerja khususnya dibidang keuangan adalah laporan keuangan, karena dengan laporan keuangan dapat diketahui perkembangan perusahaan dari masa lalu hingga masa sekarang.

Laporan keuangan pada umumnya terdiri dari neraca, laporan laba rugi, dan laporan perubahan modal atau laba yang ditahan. Dari neraca akan dapat diketahui gambaran tentang posisi keuangan, sedangkan dari analisis laporan laba rugi akan diketahui hasil (laba) yang diperoleh perusahaan. Dengan laporan keuangan, perusahaan bisa melakukan berbagai analisis sebagai dasar penilaian kinerja dan mengukur sejauh mana tujuan yang telah ditetapkan sebelumnya tercapai. Analisis yang baik adalah analisa yang dapat memberikan penilaian secara menyeluruh dan bersifat jangka panjang. Rasio dengan menggunakan Metode Radar merupakan penyempurnaan dari analisis rasio metode tradisional (DuPont) yang memberikan analisis jangka pendek. Dalam analisis metode radar ini digunakan rata-rata industri sebagai tolak ukur pengambilan kesimpulan, apakah perusahaan lebih baik atau lebih buruk dari rata-rata industri yang ada. Di sisi lain, sesempurna apapun analisis keuangan dengan menggunakan rasio atau metode-metode lain, sebaiknya tidak serta merta mengatakan bahwa analisis keuangan adalah suatu bantuan untuk mengambil keputusan yang tepat.

Tujuan dari penelitian ini adalah Mengetahui dan Menganalisis Kinerja Keuangan Dengan Metode Radar Pada Perusahaan Rokok yang Terdaftar di 
Bursa Efek Indonesia Periode 2006$2008 ?$.

\section{METODE PENELITIAN}

Objek penelitian adalah perusahaan rokok yang terdaftar di BEI tahun 2006 hingga tahun 2008.Penelitian ini termasuk dalam kelompok penelitian metode diskriptif kuantitatif. Populasi adalah totalitas dari semua subjek atau individu yang mempunyai karakteristik tertentu, jelas dan lengkap yang akan diteliti. Populasi pada penelitian ini adalah seluruh perusahaan rokok yang terdaftar di Bursa Efek Indonesia pada tahun 2006-2008. Pengambilan sampel pada penelitian ini menggunakan teknik sensus (sampling jenuh), yaitu pengambilan sampel yang dilakukan dengan mengambil seluruh populasi penelitian yang ada (Sugiyono, 2008: 122). yaitu PT Gudang Garam Tbk, PT BAT Indonesia Tbk, PT HM Sampoerna dan PT. Bentoel International Investama Tbk dijadikan sampel dalam penelitian ini. Teknik pengumpulan data mengunakan data sekunder. Teknik analisis data adalah menggunakan metode radar dengan rasio -rasio tertentu.

\section{PEMBAHASAN}

\section{Posisi Skala Rasio}

A. PT Gudang Garam Tbk

Tabel 2. Posisi Skala Rasio Tahun 2006

\begin{tabular}{|l|c|c|}
\hline \multicolumn{1}{|c|}{ Rasio } & \multicolumn{1}{c|}{$\begin{array}{c}\text { Skala Rasio } \\
\text { PT. Gudang Garam Tbk }\end{array}$} & $\begin{array}{c}\text { Posisi } \\
\text { Skala Rasio }\end{array}$ \\
\hline $\begin{array}{l}\text { PROFITABILITAS } \\
1.1 \text { ROI }\end{array}$ & 0,04637 & Normal \\
\hline 1.2 GPMR & 1,21814 & Baik \\
\hline 1.3 OMR & 0,08316 & Buruk \\
\hline 1.4 NPMR & 0.03826 & Normal \\
\hline 1.5 ROWN & 0,07660 & Normal \\
\hline 1.6 SSASE & 14,73215 & Baik \\
\hline PRODUKTIVITAS & 10.329 .715 .041 & Normal \\
2.1 SE & 178.153 .645 & Normal \\
\hline 2.2 ETL & & \\
\hline UTILIASI & & Buruk \\
AKTIVA & & Buruk \\
3.1 TATO & 1,21195 & Buruk \\
\hline 3.2 WCTO & 1,77802 & \\
\hline 3.3 ARTO & 10,51164 & \\
\hline
\end{tabular}




\begin{tabular}{|l|c|c|}
3.4 ITO & 2,26106 & Buruk \\
\hline 3.5 FATO & 3,80780 & Buruk \\
\hline STABILITAS & & Baik \\
4.1 Cushion R & 9,83361 & Buruk \\
\hline 4.2 DER & 0,05346 & Buruk \\
\hline 4.3 QR & 0,40290 & Baik \\
\hline 4.4 CR & 1,88591 & Sangat Baik \\
\hline 4.5 ICR & 0,02287 & \\
\hline POTENSI & & Normal \\
PERTUMBUHAN & & Normal \\
5.1 SG & 0,06004 & Normal \\
\hline 5.2 LSI & 1,14087 & Baik \\
\hline 5.3 NWIR & 1,00349 & \\
\hline 5.4 NPIR & 1,05512 & \\
\hline
\end{tabular}

Sumber : data diolah

PT Gudang Garam Tbk pada tahun 2006 untuk rasio profitabilitas semua berada pada posisi normal dan baik, kecuali OMR yang berada pada posisi buruk. Artinya perusahaan belum efektif dalam melakukan kegiatan operasi perusahaannya. Untuk rasio produktifitas dan rasio potensi pertumbuhan juga stabil artinya posisi perusaahaan berada pada range normal dan baik. Sedangkan untuk rasio utilisasi aktiva semuanya berada dalam posisi buruk, artinya perusahaan belum mampu mengatur perputaran aktivanya secara efektif dan efisien.

Tabel 3. Posisi Skala Rasio Tahun 2007

\begin{tabular}{|l|c|c|}
\hline \multicolumn{1}{|c|}{ Rasio } & \multicolumn{1}{c|}{$\begin{array}{c}\text { Skala Rasio } \\
\text { PT. Gudang Garam Tbk }\end{array}$} & $\begin{array}{c}\text { Posisi } \\
\text { Skala Rasio }\end{array}$ \\
\hline $\begin{array}{l}\text { PROFITABILITAS } \\
\text { 1.1 ROI }\end{array}$ & 0,06033 & Normal \\
\hline 1.2 GPMR & 1,22032 & Sangat Baik \\
\hline 1.3 OMR & 0,08980 & Buruk \\
\hline 1.4 NPMR & 0,05127 & Sangat Buruk \\
\hline 1.5 ROWN & 0,10224 & Normal \\
\hline 1.6 SSASE & 15,57297 & Sangat Baik \\
\hline PRODUKTIVITAS & & \\
2.1 SE & 65.074 .321 .549 & Buruk \\
\hline 2.2 ETL & 164.531 .707 & Normal \\
\hline UTILIASI & & \\
AKTIVA & & Buruk \\
3.1 TATO & 1,17675 & Buruk \\
\hline 3.2 WCTO & 1,63115 & Buruk \\
\hline 3.3 ARTO & 10,13735 & Buruk \\
\hline 3.4 ITO & 2,08549 & Normal \\
\hline 3.5 FATO & 4,22419 & \\
\hline
\end{tabular}


Volume 4 Nomor 1, April 2018

\begin{tabular}{|l|c|c|} 
STABILITAS & & \\
4.1 Cushion R & 7,68976 & Normal \\
\hline 4.2 DER & 0,06139 & Buruk \\
\hline 4.3 QR & 0,62918 & Sangat Buruk \\
\hline 4.4 CR & 1,93475 & Normal \\
\hline 4.5 ICR & 0,01190 & Baik \\
\hline $\begin{array}{l}\text { POTENSI } \\
\text { PERTUMBUHAN }\end{array}$ & & \\
5.1 SG & 0,06907 & Normal \\
\hline 5.2 LSI & 1,11323 & Buruk \\
\hline 5.3 NWIR & 1,07316 & Buruk \\
\hline 5.4 NPIR & 9,78106 & Baik \\
\hline
\end{tabular}

Sumber : data diolah

Pada tahun 2007 rasio profitabilitas pada PT Gudang Garam meningkat, Rasio GPMR dan SSASE meningkat pada posisi sangat baik, sedangkan rasio OMR masih tetap berada pada posisi buruk. Dan rasio yang berubah menjadi sangat buruk sedangkan pada tahun 2006 berada pada posisi normal adalah NPMR. Rasio produktifitas juga berubah pada tahun 2007 ini SE yang pada tahun 2006 berapa pada posisi normal jatuh ke posisi buruk, artinya perusahaan kurang produktif memanfaatkan karyawannya dibandingkan dengan pendapatan perusahaan yang dihasilkan.

Tabel 4. Posisi Skala Rasio Tahun 2008

\begin{tabular}{|l|c|c|}
\hline \multicolumn{1}{|c|}{ Rasio } & \multicolumn{1}{c|}{$\begin{array}{c}\text { Skala Rasio } \\
\text { PT. Gudang Garam Tbk }\end{array}$} & $\begin{array}{c}\text { Posisi } \\
\text { Skala Rasio }\end{array}$ \\
\hline $\begin{array}{l}\text { PROFITABILITAS } \\
1.1 \text { ROI }\end{array}$ & 0,07812 & Normal \\
\hline 1.2 GPMR & 1,20548 & Baik \\
\hline 1.3 OMR & 0,10464 & Normal \\
\hline 1.4 NPMR & 0,06216 & Normal \\
\hline 1.5 ROWN & 0,12117 & Normal \\
\hline 1.6 SSASE & 29,83114 & Sangat Baik \\
\hline PRODUKTIVITAS & & Sangat \\
2.1 SE & 35.914 .624 .170 & Buruk \\
\hline 2.2 ETL & 171.247 .382 & Normal \\
\hline UTILIASI & & \\
AKTIVA & & Buruk \\
3.1 TATO & 1,25666 & Buruk \\
\hline 3.2 WCTO & 1,77861 & Buruk \\
\hline 3.3 ARTO & 14,41517 & Buruk \\
\hline 3.4 ITO & 2,23606 & Buruk \\
\hline 3.5 FATO & 4,28228 & Normal \\
\hline STABILITAS & 7,99902 & \\
\hline
\end{tabular}




\begin{tabular}{|l|c|c|} 
4.1 Cushion R & & \\
\hline 4.2 DER & 0,05691 & Baik \\
\hline 4.3 QR & 0,45363 & Normal \\
\hline 4.4 CR & 2,21739 & Baik \\
\hline 4.5 ICR & 0,01828 & Normal \\
\hline POTENSI & & \\
PERTUMBUHAN & & \\
5.1 SG & 0,10450 & Normal \\
\hline 5.2 LSI & 1,06547 & Buruk \\
\hline 5.3 NWIR & 1,09911 & Baik \\
\hline 5.4 NPIR & 8,25277 & Baik \\
\hline
\end{tabular}

Sumber : data diolah

Pada tahun 2008 kemampuan perusahaan dalam menghasilkan laba berada pada posisi yang stabil. Semua rasio menunjukkan hal yang positif. Sedangkan untuk rasio produktifitas posisi SE yang pada tahun 2006 berada pada posisi buruk berubah menjadi posisi sangat buruk. Rasio utilisasi aktiva pun masih sama seperti pada tahun 2006 yaitu semua rasionya berada pada posisi buruk. Rasio stabilitas pada tahun 2008 juga berada pada posisi stabil. Sedangkan rasio potensi pertumbuhan mengalami sedikit kemajuan yaitu NWIR yang pada tahun 2007 berada pada posisi buruk berubah menjadi posisi baik pada tahun 2008 .

B. PT HM Sampoerna Tbk

Tabel 5. Posisi Skala Rasio Tahun 2006

\begin{tabular}{|l|c|c|}
\hline \multicolumn{1}{|c|}{ Rasio } & $\begin{array}{c}\text { Skala Rasio } \\
\text { PT. HM Sampoerna Tbk }\end{array}$ & $\begin{array}{c}\text { Posisi } \\
\text { Skala Rasio }\end{array}$ \\
\hline $\begin{array}{l}\text { PROFITABILITAS } \\
\text { 1.1 ROI }\end{array}$ & 0,27887 & Sangat Baik \\
\hline 1.2 GPMR & 0,28609 & Buruk \\
\hline 1.3 OMR & 0,17517 & Baik \\
\hline 1.4 NPMR & 0,11950 & Baik \\
\hline 1.5 ROWN & 0,62004 & Sangat Baik \\
\hline 1.6 SSASE & 12,24592 & Baik \\
\hline PRODUKTIVITAS & 14.440 .412 .023 & Normal \\
2.1 SE & 77.124 .774 & Buruk \\
\hline 2.2 ETL & & Baik \\
\hline UTILIASI & & Baik \\
AKTIVA & 2,33377 & Sangat Baik \\
3.1 TATO & 3,13232 & Baik \\
\hline 3.2 WCTO & 74,04579 & \\
\hline 3.3 ARTO & 3,97528 & \\
\hline 3.4 ITO & &
\end{tabular}


Volume 4 Nomor 1, April 2018

\begin{tabular}{|l|c|c|}
3.5 FATO & 9,15425 & Baik \\
\hline & & \\
\hline $\begin{array}{l}\text { STABILITAS } \\
\text { 4.1 Cushion R }\end{array}$ & 2,56063 & Buruk \\
\hline 4.2 DER & 0,22136 & Sangat Baik \\
\hline 4.3 QR & 0,35636 & Buruk \\
\hline 4.4 CR & 1,68054 & Buruk \\
\hline 4.5 ICR & 0,00295 & Baik \\
\hline $\begin{array}{l}\text { POTENSI } \\
\text { PERTUMBUHAN } \\
\text { 5.1 SG }\end{array}$ & & \\
\hline 5.2 LSI & 0,19810 & Baik \\
\hline 5.3 NWIR & 0,72340 & Buruk \\
\hline 5.4 NPIR & 1,24443 & Baik \\
\hline
\end{tabular}

Sumber : data diolah

Pada tahun 2006 rasio profitabilitas PT HM Sampoerna Tbk cenderung stabil karena semua rasio profitabilitasnya berada pada posisi baik dan sangat baik kecuali GPMR yang berada pada posisi buruk. Rasio produktivitas PT HM Sampoerna Tbk untuk SE berada pada posisi normal, sedangkan untuk ETL berada pada posisi buruk, artinya modal untuk produksi yang dipilih dibandingkan dengan tenaga kerjanya belum dijalankan dengan baik.

Tabel 6. Posisi Skala Rasio Tahun 2007

\begin{tabular}{|l|c|c|}
\hline \multicolumn{1}{|c|}{ Rasio } & $\begin{array}{c}\text { Skala Rasio } \\
\text { PT. HM Sampoerna Tbk }\end{array}$ & $\begin{array}{c}\text { Posisi } \\
\text { Skala Rasio }\end{array}$ \\
\hline PROFITABILITAS & 0,23112 & Sangat Baik \\
1.1 ROI & 0,29484 & Buruk \\
\hline 1.2 GPMR & 0,18723 & Baik \\
\hline 1.3 OMR & 0,12166 & Baik \\
\hline 1.4 NPMR & 0,44943 & Sangat Baik \\
\hline 1.5 ROWN & 12,21188 & Normal \\
\hline 1.6 SSASE & 15.322 .509 .709 & Normal \\
\hline PRODUKTIVITAS & 119.401 .220 & Buruk \\
2.1 SE & & \\
\hline 2.2 ETL & & Baik \\
\hline UTILIASI & 1,89966 & Baik \\
AKTIVA & 2,69415 & Baik \\
3.1 TATO & 29,87739 & \\
\hline 3.2 WCTO & & \\
\hline 3.3 ARTO & & \\
\hline
\end{tabular}




\begin{tabular}{|l|c|c|}
3.4 ITO & 3,33576 & Normal \\
\hline 3.5 FATO & 6,44186 & Normal \\
\hline $\begin{array}{l}\text { STABILITAS } \\
\text { 4.1 Cushion R }\end{array}$ & 1,11953 & Sangat Buruk \\
\hline 4.2 DER & 0,17383 & Normal \\
\hline 4.3 QR & 0,34230 & Buruk \\
\hline 4.4 CR & 1,77966 & Buruk \\
\hline 4.5 ICR & 0,00194 & Buruk \\
\hline $\begin{array}{l}\text { POTENSI } \\
\text { PERTUMBUHAN } \\
\text { 5.1 SG }\end{array}$ & & \\
\hline 5.2 LSI & 0,00821 & Buruk \\
\hline 5.3 NWIR & 1,10439 & Buruk \\
\hline 5.4 NPIR & 1,41616 & Baik \\
\hline
\end{tabular}

Sumber : data diolah

Untuk rasio prfitabilitas, produktivitas dan rasio utilisasi aktiva PT HM Sampoerna pada tahun 2007 masih sama posisinya dengan tahun 2006. Untuk rasio stabilitas semuanya mengalami penurunan. Rasio penyangga pada tahun 2006 berada pada posisi buruk sedangkan pada tahun 2006 berubah menjadi sangat buruk. Dan ICR pada tahun 2006 berada pada posisi baik berubah posisi pada tahun 2006 menjadi buruk.

Tabel 7. Posisi Skala Rasio Tahun 2008

\begin{tabular}{|l|c|c|}
\hline \multicolumn{1}{|c|}{ Rasio } & $\begin{array}{c}\text { Skala Rasio } \\
\text { PT. HM Sampoerna Tbk }\end{array}$ & $\begin{array}{c}\text { Posisi } \\
\text { Skala Rasio }\end{array}$ \\
\hline $\begin{array}{l}\text { PROFITABILITAS } \\
1.1 \text { ROI }\end{array}$ & 0,24144 & Baik \\
\hline 1.2 GPMR & 0,28792 & Buruk \\
\hline 1.3 OMR & 0,17950 & Baik \\
\hline 1.4 NPMR & 0,11232 & Baik \\
\hline 1.5 ROWN & 0,48401 & Baik \\
\hline 1.6 SSASE & 11,73438 & Normal \\
\hline PRODUKTIVITAS & 10.848 .487 .550 & Normal \\
2.1 SE & 150.330 .069 & Buruk \\
\hline 2.2 ETL & & \\
\hline UTILIASI & & Normal \\
AKTIVA & 2,14955 & Baik \\
3.1 TATO & 3,14212 & Baik \\
\hline 3.2 WCTO & 49,16687 & Normal \\
\hline 3.3 ARTO & 4,52875 & Normal \\
\hline 3.4 ITO & 6,80471 & Baik \\
\hline 3.5 FATO & 11,54689 & Buruk \\
\hline STABILITAS & 0,05484 & \\
4.1 Cushion R & & \\
\hline 4.2 DER & & \\
\hline
\end{tabular}




\begin{tabular}{|l|c|c|}
$4.3 \mathrm{QR}$ & 0,44221 & Normal \\
\hline $4.4 \mathrm{CR}$ & 1,44425 & Buruk \\
\hline 4.5 ICR & 0,00108 & Buruk \\
\hline POTENSI & & \\
PERTUMBUHAN & & Normal \\
5.1 SG & 0,16425 & Normal \\
\hline 5.2 LSI & 1,09564 & Normal \\
\hline 5.3 NWIR & 0,99806 & Normal \\
\hline 5.4 NPIR & 2,06606 & \\
\hline
\end{tabular}

Sumber : data diolah

Rasio profitabilitas, produktivitas, dan utilisasi aktiva masih sama seperti dua tahun sebelumnya. Sedangkan untuk SG terjadi peningkatan dari buruk menjadi baik, DER berubah dari posisi normal pada tahun 2007 menjadi buruk pada tahun 2008. Dan QR yang pada tahun 2007 berada pada posisi buruk pada tahun 2008 berada pada posisi normal. Sedangkan untuk rasio potensi pertumbuhan semuanya berada pada posisi normal.

C. PT Bentoel Internasional Investama Tbk

Tabel 8. Posisi Skala Rasio Tahun 2006

\begin{tabular}{|l|c|c|}
\hline \multicolumn{1}{|c|}{ Rasio } & $\begin{array}{c}\text { Skala Rasio } \\
\text { PT. Bentoel Internasional } \\
\text { Investama Tbk }\end{array}$ & $\begin{array}{c}\text { Posisi } \\
\text { Skala Rasio }\end{array}$ \\
\hline $\begin{array}{l}\text { PROFITABILITAS } \\
1.1 \text { ROI }\end{array}$ & 0,06197 & Normal \\
\hline 1.2 GPMR & 0,00044 & Buruk \\
\hline 1.3 OMR & 0,07250 & Buruk \\
\hline 1.4 NPMR & 0,06336 & Buruk \\
\hline 1.5 ROWN & 0,12217 & Buruk \\
\hline 1.6 SSASE & 7,27707 & Sangat Buruk \\
\hline $\begin{array}{l}\text { PRODUKTIVITAS } \\
\text { 2.1 SE }\end{array}$ & 5.311 .504 .739 & Sangat Buruk \\
\hline 2.2 ETL & 85.507 .588 & Buruk \\
\hline $\begin{array}{l}\text { UTILIASI } \\
\text { AKTIVA }\end{array}$ & & Buruk \\
\hline 3.1 TATO & 0,97810 & Normal \\
\hline 3.2 WCTO & 1,35633 & Buruk \\
\hline 3.3 ARTO & 2,24308 & Buruk \\
\hline 3.4 ITO & 2,72522 & Normal \\
\hline 3.5 FATO & 3,50742 & Normal \\
\hline $\begin{array}{l}\text { STABILITAS } \\
\text { 4.1 Cushion R }\end{array}$ & 6,32866 & \\
\hline 4.2 DER & 0,08687 & \\
\hline
\end{tabular}




\begin{tabular}{|l|c|c|} 
4.3 QR & 0,80734 & Sangat Baik \\
\hline 4.4 CR & 1,60727 & Buruk \\
\hline 4.5 ICR & $-0,01904$ & Sangat Buruk \\
\hline $\begin{array}{l}\text { POTENSI } \\
\text { PERTUMBUHAN } \\
\text { 5.1 SG }\end{array}$ & & \\
\hline 5.2 LSI & 0,37696 & Baik \\
\hline 5.3 NWIR & 1,88091 & Sangat Baik \\
\hline 5.4 NPIR & 1,06908 & Normal \\
\hline
\end{tabular}

Sumber : data diolah

Untuk Rasio profitabilitas PT Bentoel Internasional Investama pada tahun 2006 berada dalam kondisi yang kurang stabil karena dari enam rasio profitabilitas hanya 2 rasio yang berada pada posisi normal. Artinya kemampuan perusahaan untuk menghasilkan dan memanage keuntungan yang diperoleh belum meksimal. Begitu pula dengan rasio produktivitasnya juga berada pada posisi sangat buruk. Untuk rasio utilisasi aktiva hanya ARTO yang berada pada posisi normal sedangkan keempat rasio lainnya berada pada posisi buruk. Untuk rasio stabilitas pada tahun 2006 Cushion Ratio, DER dan QR berada pada posisi normal dan sangat baik sedangkan untuk CR dan ICR berada pada posisi buruk dan sangat buruk.

Tabel 9. Posisi Skala Rasio Tahun 2007

\begin{tabular}{|l|c|c|}
\hline \multicolumn{1}{|c|}{ Rasio } & $\begin{array}{c}\text { Skala Rasio } \\
\text { PT. Bentoel Internasional } \\
\text { Investama Tbk }\end{array}$ & $\begin{array}{c}\text { Posisi } \\
\text { Skala Rasio }\end{array}$ \\
\hline $\begin{array}{l}\text { PROFITABILITAS } \\
1.1 \text { ROI }\end{array}$ & 0,06295 & Normal \\
\hline 1.2 GPMR & 0,21914 & Buruk \\
\hline 1.3 OMR & 0,07486 & Buruk \\
\hline 1.4 NPMR & 0,05297 & Normal \\
\hline 1.5 ROWN & 0,15758 & Normal \\
\hline 1.6 SSASE & 10,91555 & Buruk \\
\hline PRODUKTIVITAS & 12.130 .101 .256 & Buruk \\
2.1 SE & 107.365 .195 & Buruk \\
\hline 2.2 ETL & & \\
\hline UTILIASI & & Buruk \\
AKTIVA & 1,18834 & Buruk \\
\hline 3.1 TATO & 1,46142 & Baik \\
\hline 3.2 WCTO & 26,59906 & Buruk \\
\hline 3.3 ARTO & 2,17684 & Buruk \\
\hline 3.4 ITO & 2,17684 & Buruk \\
\hline 3.5 FATO & 0,48893 & \\
\hline STABILITAS & &
\end{tabular}




\begin{tabular}{|l|c|c|} 
4.1 Cushion R & & \\
\hline 4.2 DER & 0,95679 & Sangat Baik \\
\hline 4.3 QR & 1,22377 & Baik \\
\hline 4.4 CR & 3,72363 & Sangat Baik \\
\hline 4.5 ICR & 0,02007 & Sangat Baik \\
\hline $\begin{array}{l}\text { POTENSI } \\
\text { PERTUMBUHAN }\end{array}$ & & \\
5.1 SG & 0,53045 & Sangat Baik \\
\hline 5.2 LSI & 1,82877 & Sangat Baik \\
\hline 5.3 NWIR & 1,29428 & Baik \\
\hline 5.4 NPIR & 6,34588 & Baik \\
\hline
\end{tabular}

Sumber : data diolah

Terjadi peningkatan dari tahun sebelumnya untuk rasio profitabilitas, walaupun untuk GPMR, OMR dan SSASE masih berada pada posisi yang sama yaitu buruk. Walaupun terjadi peningkatan tetapi rasio produktivitas pada tahun 2007 belum maksimal, karena posisinya masih berada pada range buruk. Tidak banyak berubah dari tahun 2006 untuk rasio utilisasi aktiva keempat rasio masih berada pada posisi buruk sedangkan ARTO yang pada tahun 2006 berada pada posisi normal meningkat pada posisi baik.

Tabel 10. Posisi Skala Rasio Tahun 2008

\begin{tabular}{|l|c|c|}
\hline \multicolumn{1}{|c|}{ Rasio } & $\begin{array}{c}\text { Skala Rasio } \\
\text { PT. Bentoel Internasional } \\
\text { Investama Tbk }\end{array}$ & $\begin{array}{c}\text { Posisi } \\
\text { Skala Rasio }\end{array}$ \\
\hline $\begin{array}{l}\text { PROFITABILITAS } \\
1.1 \text { ROI }\end{array}$ & 0,05367 & Normal \\
\hline 1.2 GPMR & 0,18796 & Buruk \\
\hline 1.3 OMR & 0,06904 & Normal \\
\hline 1.4 NPMR & 0,04025 & Normal \\
\hline 1.5 ROWN & 0,13821 & Normal \\
\hline 1.6 SSASE & 12,43341 & Normal \\
\hline & & Buruk \\
\hline PRODUKTIVITAS & 10.848 .487 .550 & Normal \\
2.1 SE & 176.929 .678 & \\
\hline 2.2 ETL & & Buruk \\
\hline UTILIASI & & Buruk \\
AKTIVA & 1,33335 & \\
3.1 TATO & 1,94585 & \\
\hline 3.2 WCTO & & \\
\hline
\end{tabular}




\begin{tabular}{|l|c|c|} 
3.3 ARTO & 43,10180 & Baik \\
\hline 3.4 ITO & 2,24676 & Buruk \\
\hline 3.5 FATO & 4,23597 & Buruk \\
\hline STABILITAS & 0,93910 & Sangat Buruk \\
4.1 Cushion R & 0,86314 & Sangat Baik \\
\hline 4.2 DER & 0,33192 & Buruk \\
\hline 4.3 QR & 2,47830 & Baik \\
\hline 4.4 CR & 0,02976 & Baik \\
\hline 4.5 ICR & & \\
\hline POTENSI & & Baik \\
PERTUMBUHAN & 0,29542 & Sangat Baik \\
5.1 SG & 1,30917 & Baik \\
\hline 5.2 LSI & 1,12240 & Baik \\
\hline 5.3 NWIR & 7,23516 & \\
\hline 5.4 NPIR & &
\end{tabular}

Sumber : data diolah

Dibandingkan dengan tahun 2006 dan 2007 pada tahun 2008 rasio profitabilitas untuk PT Bentoel Internasional Investama berada pada posisi normal, hanya GPMR yang masih berada pada posisi buruk. Peningkatan juga terjadi pada rasio produktivitas, selama 2 tahun sebelumnya rasio produktivitas berada pada posisi buruk sedangkan pada tahun 2008 untuk ETL meningkat pada posisi normal.

D. PT BAT Indonesia Tbk

Tabel 11. Posisi Skala Rasio Tahun 2006

\begin{tabular}{|l|c|c|}
\hline \multicolumn{1}{|c|}{ Rasio } & $\begin{array}{c}\text { Skala Rasio } \\
\text { PT. BAT Indonesia Tbk }\end{array}$ & $\begin{array}{c}\text { Posisi } \\
\text { Skala Rasio }\end{array}$ \\
\hline $\begin{array}{l}\text { PROFITABILITAS } \\
1.1 \text { ROI }\end{array}$ & $-0,10151$ & Buruk \\
\hline 1.2 GPMR & 0,77000 & Normal \\
\hline 1.3 OMR & 0,14150 & Baik \\
\hline 1.4 NPMR & $-0,04528$ & Sangat Buruk \\
\hline 1.5 ROWN & $-0,17700$ & Buruk \\
\hline 1.6 SSASE & 7,77774 & Buruk \\
\hline PRODUKTIVITAS & 42.514 .160 .005 & Sangat Baik \\
2.1 SE & 283.218 .813 & Sangat Baik \\
\hline 2.2 ETL & & \\
\hline UTILIASI & & Baik \\
AKTIVA & 2,24213 & Baik \\
3.1 TATO & 3,22911 & Normal \\
\hline 3.2 WCTO & 22,35313 & Baik \\
\hline 3.3 ARTO & 4,19162 & \\
\hline 3.4 ITO & &
\end{tabular}




\begin{tabular}{|l|c|c|}
3.5 FATO & 7,33564 & Baik \\
\hline $\begin{array}{l}\text { STABILITAS } \\
\text { 4.1 Cushion R }\end{array}$ & 6,83998 & Normal \\
\hline 4.2 DER & 0,07792 & Normal \\
\hline 4.3 QR & 0,41761 & Normal \\
\hline 4.4 CR & 1,81864 & Baik \\
\hline 4.5 ICR & & \\
\hline $\begin{array}{l}\text { POTENSI } \\
\text { PERTUMBUHAN } \\
\text { 5.1 SG }\end{array}$ & & \\
\hline 5.2 LSI & $-0,09156$ & Buruk \\
\hline 5.3 NWIR & 1,05642 & Normal \\
\hline 5.4 NPIR & 0,84962 & Buruk \\
\hline Sumber: & $-5,64961$ & Buruk \\
\hline
\end{tabular}

Sumber : data diolah

Pada tahun 2006 rasio profitabilitas PT BAT Indonesia Tbk belum stabil, walaupun GPMR dan OMR berada pada posisi normal dan baik tetapi untuk keempat rasio lainnya yaitu ROI, NPMR dan ROWN dan SSASE berada pada posisi buruk dan sangat buruk. Sedangkan untuk rasio produktivitas, utilisasi aktiva dan stabilitas semua berada pada posisi di atas rata-rata industri.

Tabel 12. Posisi Skala Rasio Tahun 2007

\begin{tabular}{|l|c|c|}
\hline \multicolumn{1}{|c|}{ Rasio } & \multicolumn{1}{c|}{$\begin{array}{c}\text { Skala Rasio } \\
\text { PT. BAT Indonesia Tbk }\end{array}$} & $\begin{array}{c}\text { Posisi } \\
\text { Skala Rasio }\end{array}$ \\
\hline $\begin{array}{l}\text { PROFITABILITAS } \\
1.1 \text { ROI }\end{array}$ & $-0,05064$ & Buruk \\
\hline 1.2 GPMR & 0,71547 & Normal \\
\hline 1.3 OMR & 0,14447 & Normal \\
\hline 1.4 NPMR & $-0,02204$ & Buruk \\
\hline 1.5 ROWN & $-0,10179$ & Buruk \\
\hline 1.6 SSASE & 10,83171 & \\
\hline PRODUKTIVITAS & 65.074 .321 .549 & Sangat Baik \\
2.1 SE & 292.759 .668 & Sangat Baik \\
\hline 2.2 ETL & & \\
\hline UTILIASI & & Baik \\
AKTIVA & 2,29738 & Baik \\
3.1 TATO & 3,09887 & Buruk \\
\hline 3.2 WCTO & 10,20926 & Sangat Baik \\
\hline 3.3 ARTO & 6,96831 & Baik \\
\hline 3.4 ITO & 8,88253 & Normal \\
\hline 3.5 FATO & & Buruk \\
\hline STABILITAS & 8,60894 & Normal \\
\hline 4.1 Cushion R & 0,06039 & \\
\hline 4.2 DER & 0,87130 & \\
\hline 4.3 QR & & \\
\hline
\end{tabular}




\begin{tabular}{|l|c|c|} 
4.4 CR & 1,56909 & Buruk \\
\hline 4.5 ICR & & \\
\hline POTENSI & & \\
PERTUMBUHAN & 0,13140 & Normal \\
5.1 SG & 1,33901 & Normal \\
\hline 5.2 LSI & 0,95780 & Buruk \\
\hline 5.3 NWIR & $-9,82407$ & Sangat Buruk \\
\hline 5.4 NPIR & & \\
\hline
\end{tabular}

Sumber : data diolah

Pada tahun 2007 rasio pofitabilitas dan rasio produktivitas tidak ada yang mengalami perubahan, sedangkan untuk rasio utilisasi aktiva juga masih sama seperti tahun sebelumnya hanya ARTO yang pada tahun 2006 berada pada posisi normal pada tahun 2008 berada pada posisi buruk.

Tabel 13. Posisi Skala Rasio Tahun 2008

\begin{tabular}{|c|c|c|}
\hline Rasio & $\begin{array}{c}\text { Skala Rasio } \\
\text { PT. BAT Indonesia Tbk }\end{array}$ & $\begin{array}{c}\text { Posisi } \\
\text { Skala Rasio }\end{array}$ \\
\hline $\begin{array}{l}\text { PROFITABILITAS } \\
1.1 \text { ROI }\end{array}$ & $-0,16413$ & Buruk \\
\hline 1.2 GPMR & 0,78810 & Normal \\
\hline $1.3 \mathrm{OMR}$ & $-0,05339$ & Sangat Buruk \\
\hline 1.4 NPMR & $-0,04377$ & Sangat Buruk \\
\hline 1.5 ROWN & $-0,34712$ & Sangat Buruk \\
\hline 1.6 SSASE & 8,12254 & Buruk \\
\hline $\begin{array}{l}\text { PRODUKTIVITAS } \\
2.1 \mathrm{SE}\end{array}$ & 35.914 .642 .170 & Sangat Baik \\
\hline $2.2 \mathrm{ETL}$ & 298.438 .202 & Sangat Baik \\
\hline $\begin{array}{l}\text { UTILIASI } \\
\text { AKTIVA } \\
3.1 \text { TATO }\end{array}$ & 2,68917 & Baik \\
\hline $3.2 \mathrm{WCTO}$ & 3,84899 & Baik \\
\hline 3.3 ARTO & 18,88971 & Buruk \\
\hline 3.4 ITO & 12,08573 & Sangat Baik \\
\hline 3.5 FATO & 8,92435 & Baik \\
\hline $\begin{array}{l}\text { STABILITAS } \\
\text { 4.1 Cushion R }\end{array}$ & 6,34100 & Normal \\
\hline 4.2 DER & 0,10050 & Normal \\
\hline $4.3 \mathrm{QR}$ & 0,99275 & Sangat Baik \\
\hline $4.4 \mathrm{CR}$ & 1,45665 & Buruk \\
\hline $4.5 \mathrm{ICR}$ & & \\
\hline $\begin{array}{l}\text { POTENSI } \\
\text { PERTUMBUHAN } \\
\text { 5.1 SG }\end{array}$ & $-0,08974$ & Sangat Buruk \\
\hline $5.2 \mathrm{LSI}$ & 1,10754 & Sangat Buruk \\
\hline $5.3 \mathrm{NWIR}$ & 0,74232 & Sangat Buruk \\
\hline
\end{tabular}




\begin{tabular}{|l|l|l|} 
5.4 NPIR & $-4,01685$ & Sangat Buruk \\
\hline Sumber : data diolah &
\end{tabular}

Rasio profitablitas PT BAT Indonesia Tbk pada tahun 2008 menurun, dari keenam rasio hanya GPMR yang masih berada pada posisi normal sedangkan rasio lainnya semuanya berada pada posisi dibawah rata-rata. Rasio produktivitas masih sama seperti 2 tahun sebelumnya, yaitu berada pada posisi sangat baik.

\section{Kesimpulan}

1. Hasil seluruh rasio profitabilitas PT Gudang Garam dari tahun 2006 sampai dengan 2008 selalu berada di dalam range normal atau baik dan sangat baik. Dari dua rasio produktivitas menghasilkan kondisi yang normal untuk ETL. Sedangkan untuk SE tidak begitu baik karena hanya pada tahun 2006 perusahaan berada pada posisi normal sedangkan pada tahun 2007 perusahaan berada pada posisi buruk dan tahun 2008 menjadi sangat buruk. PT Gudang Garam Tbk memiliki tingkat efektivitas dan efisiensi penggunaan aktiva yang sangat tidak stabil.

2. Pada tahun 2006 sampai dengan tahun 2008 rasio profitabilitas menunjukkan nilai yang berada pada posisi normal kecuali GPMR Produktivitas perusahaan dari tahun 2006 hingga 2008 berada pada posisi buruk. Walaupun ditahun 2006 rasio produktivitas menunjukkan hail yang kurang maksimal tetapi perusahaan berusaha meningkatkan kinerjanya dari tahun ke tahun. PT Bentoel Internasional Investama Tbk memiliki tingkat efektivitas dan efisiensi dalam penggunaan aktiva yang buruk. PT BAT Indonesia memiliki jumlah tenaga kerja yang paling sedikit jika dibandingkan dengan perusahaan rokok yang lain. Hal ini menunjukkan perusahaan sangat baik dalam memanajemeni jumlah tenaga kerja yang dimiliki. Hal ini terbukti dari hasil SE dan ETL yang selalu berada dalam posisi sangat baik.

\section{DAFTAR PUSTAKA}

Abdullah, M. Faisal.2002. Dasar-Dasar Manajemen Keuangan. Edisi Kedua.UMM. Press. Malang.

Al Haryono Jusuf.2005.Dasar-dasar Akuntansi.Edisi Enam.Bagian Penerbitan Sekolah Tinggi Ilmu Ekonomi YKPN.Yogyakarta.

Anto Dajan.2000.Pengantar Metode Statistik.LP3ES.Jakarta. Arifin, Johar. 2004. Analisis Laporan Keuangan Berbasis Komputer. 
PT.Gramedia Pustaka Utama, Jakarta.

Bambang Hermanto. 1993.

Memperkenalkan Analisa

Rasio dengan Metode Radar.

Usahawan,Edisi Mei no 5.Thn

XXII.Lembaga Maanjemen FE

UI.Jakarta.

Dian Nugraha Perdana.2009.Analisis

Profitabilitas pada Perusahaan

Rokok yang Listing di Bursa

Efek Indonesia periode 2003 -

2008.Program

Studi

Manajemen.Skripsi.Universitas

Lambung

Mangkurat.Banjarmasin.

Dwi Prastowo, Rifka

Julianty.2002.Analisis Laporan

Keuangan.UPP

AMP

YKPN.Yogyakarta.

Ikatan Akuntansi Indonesia, 2004.

Standar Akuntansi Keuangan.

Salemba Empat. Jakarta.

Luqieta Serie Ria.2007.Analisis Kinerja

Keuangan Perusahaan Rokok

Menggunakan Metode Radar

(Studi pada Perusahaan Rokok yang Terdaftar di BEJ).Jurnal

Skripsi.Universitas

Brawijaya.Malang.

Mary Handoko W, Izzatul

Ummah.2009.Perancangan

Model Sistem Analisis Kinerja

\section{Keuangan Perusahaan \\ (Pendekatan Sistem}

Dinamik).Jurnal.Seminar

Nasional Aplikasi Teknologi Informasi (SNATI). Yogyakarta.

M.Hanafi dan Abdul

Halim.1995.Analisa Laporan

Keuangan.YKPN.Yogyakarta.

M.Nafarin.2004.Penganggaran

Perusahaan.Edisi

Revisi.Salemba Empat.Jakarta.

Nina Wati.2008.Analisis Kinerja

Keuangan Perusahaan

Menggunakan DuPont

Framework Pada Perusahaan

Rokok yang Terdaftar di Bursa

Efek Jakarta.Skripsi.Universitas

Lambung

Mangkurat.Banjarmasin

S.Munawir.2004.Analisa Laporan

Keuangan.Edisi Keempat.

Liberty Yogyakarta, Yogyakarta.

Sofyan Safri Harahap.2008. Analisis

Kritis Atas Laporan Keuangan.

PT.Raja Grafindo Persada,

Jakarta.

Sugiono, 2004. Metode Penelitian

Bisnis. Alfabeta, Bandung.

Warsono, 2003.Manajemen Keuangan

Perusahaan.Jilid 1. Penerbit

Banyumedia Publishing, Malang

http://www.jsx.co.id

http://www.kontan.co.id 